\title{
The Influence of Flunixin on the Response to Salmonella typhimurium Endotoxin in Calves
}

\author{
By J. Luthman, H. Kindahl and S. O. Jacobsson \\ Department of Cattle and Sheep Diseases and Department of Obstetrics and Gynaecology, \\ Faculty of Veterinary Medicine, \\ Swedish University of Agricultural Sciences, Uppsala, Sweden.
}

\begin{abstract}
Luthman, J., H. Kindahl and S. O. Jacobsson: The influence of flunixin on the response to Salmonella typhimurium endotoxin in calves. Acta vet. scand. 1989, 30, 295-300. - The effects of intravenous injection of $0.5 \mu \mathrm{g} / \mathrm{kg}$ body weight of Salmonella typhimurium endotoxin were studied in calves. The injection was followed by ruminal stasis and general dullness. The clinical signs disappeared within 24 hours.

The injection was followed by a tremendous increase in the plasma level of 15-ketodihydro-PGF $\mathrm{PG}_{2 \alpha}$, the main metabolite of $\mathrm{PGF}_{2 \alpha}$. The injection was also associated with a profound leukopenia and significant decreases in the serum levels of iron, zinc and calcium. In order to study the role of prostaglandin (PG) for the development of endotoxin-induced changes a group of calves was pretreated with flunixin, a potent cyclo-oxygenase inhibitor, at a dose of $2.2 \mathrm{mg} / \mathrm{kg}$ body weight. Flunixin inhibited the PG release completely, but did not influence the other responses to endotoxin.

The pyrogenic response to endotoxin was very moderate and it was suggested that fever is not the most suitable parameter for monitoring endotoxin effects in calves. The studied blood parameters (15-ketodihydro- $\mathrm{PGF}_{2 \alpha}$, iron, zinc, calcium and the number of leukocytes) appeared to be much more sensitive.
\end{abstract}

leukopenia; calcium; iron; zinc; prostaglandin .

\section{Introduction}

Intravenous injection of endotoxin is followed by a chain of reactions. A tremendous increase in the plasma level of prostaglandin $\mathrm{F}_{2 \alpha}\left(\mathrm{PGF}_{2 \alpha}\right)$ was reported by Fredriksson (1984) and it seems clear that endotoxin-induced luteolysis is mediated by $\mathrm{PFG}_{2 \alpha}$. Vasoactive PGs are obviously involved in the hemodynamic changes associated with endotoxin injection (e.g. reduced mean arterial pressure, increased pulmonary artery pressure), since these changes can be reduced by inhibitors of PG synthesis (Schrauwen et al. 1984, Margolis et al. 1987).

Other well known effects of endotoxin are e.g. fever, leukopenia, hypocalcaemia, hypoglycaemia, decreases of serum iron and zinc and inhibition of gastric motility (Van Miert, 1985, 1987). These changes are considered to be induced by endogenous mediators produced by activated leukocytes and cells of the reticuloendothelial system. The litterature on these mediators, endogenous pyrogen (EP) and leukocytic endogenous mediator (LEM), is abundant (for reviews see Mitchell and Kampschmidt, 1985, Bernheim, 1985). EP is shown to act by increasing the PG levels in the temperature regulating centre (Milton, 1982). It is therefore possible to prevent endotoxin-induced fever 
by PG synthesis inhibitors. The decrease in the serum levels of iron and zinc is shown to be due to a LEM-induced redistribution of the elements (Pekarek and Beisel, 1971, Beisel, 1977). The alterations in trace element kinetics was not possible to inhibit by flurbiprofen, a blocker of PG synthesis (Van Miert et al. 1982).

Hypocalcaemia in dairy cows after injection of E.coli endotoxin was described by Griel et al. (1975). The mechanism behind endotoxin-induced hypocalcaemia is not known. There are however indications that PG may be involved, since it was earlier reported that intravenous infusion of PG caused hypocalcaemia in cows (Luthman et al. 1983) and in goats (Fredriksson, 1984).

The aim of the present investigation was to further study the role of PG as mediators of some endotoxin-induced changes by using flunixin, a potent cyclo-oxygenase inhibitor. The role of PG for the development of hypocalcaemia was considered to be of special interest.

\section{Material and methods}

The calves used in the present study were all of the Swedish Red and White breed. The 10 calves showed a mean weight of about 100 kg. Lipopolysaccharide (LPS) from Salmonella typhimurium was used at a dose of 0.5 $\mu \mathrm{g} / \mathrm{kg}$ body weight. The preparation of LPS was earlier described by Fredriksson (1984). The effect of LPS after intravenous injection was studied in 4 calves. Blood was sampled at intervals shown in Fig. 1 and Table 2 for leukocyte counting and analysis of 15ketodihydro- $\mathrm{PGF}_{2 \alpha}$, calcium, iron and zinc. The effect of flunixin (Finadyne vet., 50 $\mathrm{mg} / \mathrm{ml}$, Essex Läkemedel, Stockholm, Sweden) on the studied parameters and the influence of the drug on the response to LPS was studied in an experiment using a crossover design. Six calves were used in this stu- dy. All animals were given an intravenous injection of flunixin at a dose of $2.2 \mathrm{mg} / \mathrm{kg}$ body weight. Three of the animals received an intravenous injection of LPS $(0.5 \mu \mathrm{g} / \mathrm{kg})$ $10 \mathrm{~min}$ after the flunixin injection. The experiment was repeated after 1 week when the 3 remaining animals were injected with LPS. 15 -Ketodihydro- $\mathrm{PGF}_{2 \alpha}$ in plasma was analyzed according to Granström and Kindahl (1982). Calcium, zinc and iron in serum were analyzed by atomic absorption spectrophotometry. Blood leukocytes were counted in a celloscope (Linson Instrument AB, Stockholm). Changes in body temperature were recorded by an electronic thermometer which was inserted at least $8 \mathrm{~cm}$ in the rectum.

Student's t-test for paired data was used for statistical calculations. The values given in the text are means \pm standard error of the mean.

\section{Results}

LPS caused pronounced clinical signs. All animals showed forced breathing and increased salivation after about $1 \mathrm{~h}$. Signs of ruminal stasis were obvious after about $2 \mathrm{~h}$ and the calves laid down and appeared mentally depressed. The clinical signs disappeared gradually and all animals recovered completely within $24 \mathrm{~h}$. Flunixin caused no clinical signs and reduced, but did not abolish, the clinical signs after LPS injection.

LPS gave a very moderate pyrogenic response (Table 1). The LPS group (group B) consisted only of 4 animals, the mean temperature recorded after $6 \mathrm{~h}$ was however significantly higher than the preinjection value. Flunixine alone (group A) did not cause any significant changes in body temperature. In the group treated with flunixin + LPS (group C) the value obtained after $4 \mathrm{~h}$ was significantly higher than the preinjection level. 
Table 1. Body temperature (mean and s.e.m.) by $\mathrm{h}$ in calves after injection of endotoxin $(0.5 \mathrm{~g} / \mathrm{kg}$ body weight) and flunixin $(2.2 \mathrm{mg} / \mathrm{kg}$ body weight).

\begin{tabular}{ccccccccc}
\hline & \multicolumn{7}{c}{ Hours after injection } \\
& 0 & 1 & 2 & 4 & 6 & 8 & 10 & 24 \\
\hline A & 38.7 & 38.6 & 38.7 & 38.4 & 38.5 & 38.7 & 38.8 & 38.7 \\
& 0.12 & 0.14 & 0.16 & 0.14 & 0.13 & 0.11 & 0.18 & 0.18 \\
B & 38.5 & 39.0 & 38.8 & 38.6 & $38.9^{*}$ & 38.7 & 38.7 & 38.5 \\
& 0.04 & 0.15 & 0.20 & 0.17 & 0.13 & 0.07 & 0.07 & 0.07 \\
C & 38.6 & 38.9 & 39.1 & $39.3^{*}$ & 38.6 & 38.4 & 38.6 & 38.8 \\
& 0.05 & 0.06 & 0.14 & 0.16 & 0.11 & 0.08 & 0.13 & 0.11 \\
\hline
\end{tabular}

\begin{tabular}{lll}
\hline A & Flunixin meglumine, $2.2 \mathrm{mg} / \mathrm{kg}$ i.v. & $\mathrm{n}=6$ \\
$\mathrm{~B}$ & Endotoxin, $0.5 \mu \mathrm{g} / \mathrm{kg}$ i.v. & $\mathrm{n}=4$ \\
$\mathrm{C}$ & $\begin{array}{l}\text { Flunixin meglumine, } 2.2 \mathrm{mg} / \mathrm{kg}+\mathrm{n}=6 \\
\text { endotoxin, } 0.5 \mu \mathrm{g} / \mathrm{kg}\end{array}$
\end{tabular}

*significantly different from the preinjection level $0,01<\mathrm{p}<0.05$

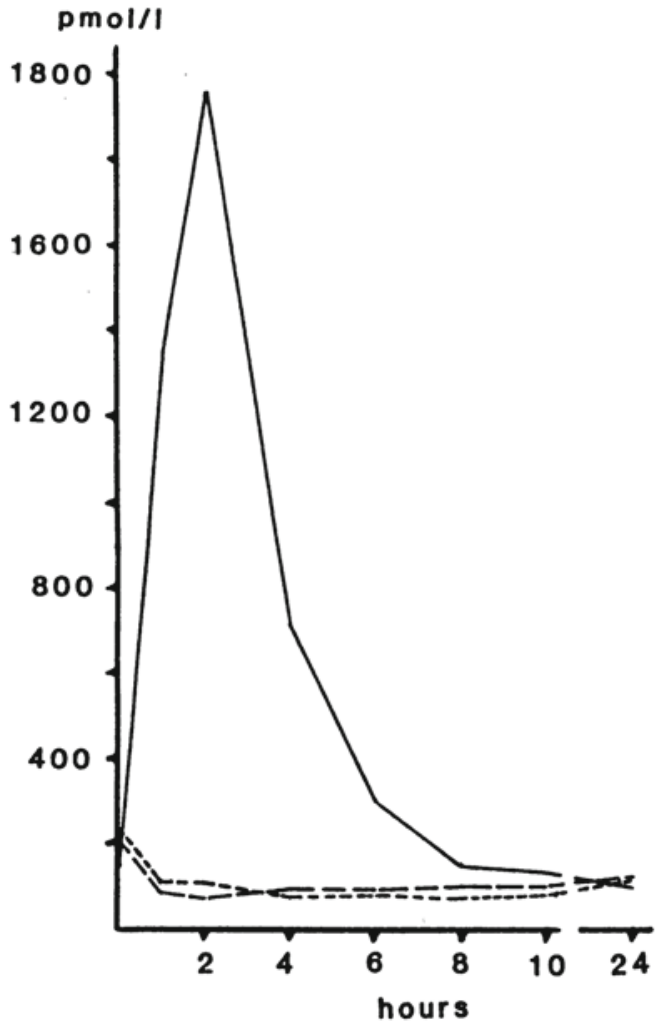

Figure 1. Changes in the plasma concentration of 15-ketodihydro $\mathrm{PGF}_{2 \alpha}$ after injection of $0.5 \mu \mathrm{g} / \mathrm{kg}$ of LPS $(n=4)$ $2.2 \mathrm{mg} / \mathrm{kg}$ of flunixin $(\mathrm{n}=6)$ $\ldots$ and $2.2 \mathrm{mg} / \mathrm{kg}$ of flunixin $+0.5 \mu \mathrm{g} / \mathrm{kg}$ of LPS $(\mathrm{n}=6) \ldots$. .
LPS caused a tremendous increase in plasma 15-ketodihydro- $\mathrm{PGF}_{2 \alpha}$ (Fig. 1). The level increased from $161 \pm 13 \mathrm{pmol} / 1$ to a maximum of $1949 \pm 451 \mathrm{pmol} / 1$ which was reached after $2 \mathrm{~h}$. The level remained elevated for about $6 \mathrm{~h}$. Flunixin lowered the plasma level of the $\mathrm{PGF}_{2 \alpha}$ metabolite significantly during the whole observation period (from 1 to $24 \mathrm{~h}, \mathrm{p}<0.001$ ). Pretreatment with flunixin did not only abolish the effect of LPS, but even decreased the $\mathrm{PGF}_{2 \alpha}$ metabolite level significantly ( $\mathrm{p}<0.001$ from 1 to $24 \mathrm{~h}$ ). The well known effects of LPS on the serum levels of calcium, iron and zinc and on the number of circulating leukocytes were confirmed (Table 2). As shown in the table flunixin did not modify these response to LPS.

\section{Discussion}

Injected LPS is rapidly removed from the circulation and is primarily taken up by the reticuloendothelial system (Dinarello, 1983). Most of the observed effects of LPS are shown to be due not to LPS per se, but to endogenous mediators whose production and release is initiated by LPS.

EP and LEM are generally accepted as mediators of fever and changes in trace element kinetics. These groups of mediators are very 
Table 2. Total number of blood leukocytes and serum concentrations of calcium, zinc and iron in calves after intravenous injection of endotoxin $(0.5 \mu \mathrm{g} / \mathrm{kg}$ body weight $)$ and flunixin $(2.2 \mathrm{mg} / \mathrm{kg}$ body weight $) . \mathrm{x} \pm \mathrm{s} . \mathrm{e} . \mathrm{m}$.

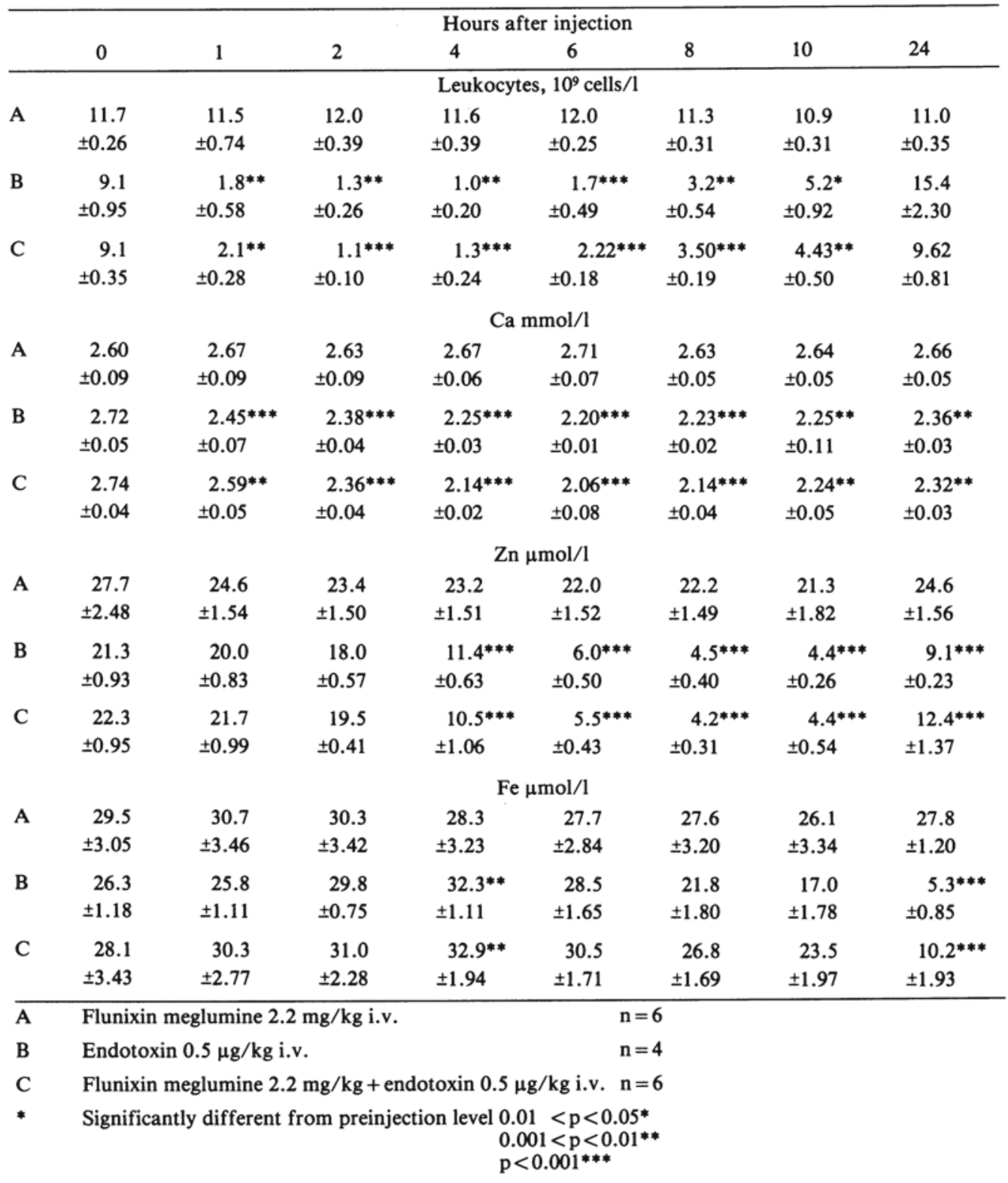


similar and was recently renamed interleukin-1 (Oppenheim et al. 1986).

Fever is generally a very regular response to LPS. The pyrogenic response was however very irregular in the present study. Similar results were reported from an earlier calf study (Luthman et al. 1988). Cattle is not as sensitive to LPS as some other species (Van Miert, 1985) and the antipyretic effect of flunixin can not be fully evaluated from the results shown in Table 1.

The changes in the serum levels of iron and zinc are in good agreement with the results from previous calf studies (Depelchin et al. 1985, Luthman et al. 1988). These changes are due to a redistribution within the body. Sankari and Pekkanen (1982) showed that the zinc content of the rat liver increased from 40 to $120 \mathrm{mg} / \mathrm{kg}$ within the first $12 \mathrm{~h}$ after LPS injection. PGs are obviously not involved in the trace element changes as flunixin completely abolished the PG release, but had no effect on the trace element response (Fig. 1, Table 2). Similar results were reported by Van Miert et al. (1982), who used flurbiprofen, another potent cyclooxygenase inhibitor.

Flunixin did not alter the serum calcium response to LPS (Table 2). The causes to this type of hypocalcaemia are unknown. Other mediators than PG must be involved. Hypothetically the hypocalcaemia may, as the decreases in iron and zinc, be caused by a EP/LEM induced redistribution. Another possibility is that LPS causes a pronounced release of the serum calcium lowering hormone thyrocalcitonin.

Leukopenia is probably a direct effect of LPS, since MacGregor (1977) reported that LPS significantly increased the adherence of leukocytes. Leukopenia may thus be due to a shift from the circulating to the marginated pool. As shown in Table 2 flunixin did not influence the LPS-induced leukopenia.
The results given in Table 2 were obtained from an experiment of crossover design. It seems not probable that the first injections of flunixin and LPS influenced the results obtained 1 week later. The elimination halflife of flunixin in cattle is $8-12 \mathrm{~h}$ according to Hardee et al. (1985). These authors calculated from available pharmacokinetic data that for analgesia in cattle the initial dose should be $2.2 \mathrm{mg} / \mathrm{kg}$ body weight followed by $1.1 \mathrm{mg} / \mathrm{kg}$ each 8 th hour.

The results from the present study showed that flunixin is a potent inhibitor of PG release. The clinical signs following LPS injection was reduced, but not eliminated by flunixin. It can also be concluded that PG is not involved in LPS-induced leukopenia and decreases in the serum levels of iron, zinc and calcium. Fever is a classical response to LPS, but the results suggest that fever is not the most suitable parameter for monitoring LPS effects in calves. The studied blood chemical parameters appear to be much more sensitive.

\section{References}

Beisel RW: Magnitude of the host nutritional responses to infection. Amer. J. clin. Nutr. 1977, 30, 1236-1247.

Bernheim HA: Temperature regulation and fever. In: The Reticuloendothelial System. A. Comprehensive Treatise. Ed. Reichard SM and Filkins OP. Plenum Press, New York, 1985.

Depelchin Bo, Bloden S, Hooremans M, Noirfalise $A$, Ansay M: Clinical and experimental modifications of plasma iron and zinc concentrations in cattle. Vet. Rec. 1985, 116, 519-521.

Dinarello CA: Molecular mechanisms in endotoxin fever. Agents and Actions, 1983, 13, 470-485.

Fredriksson G: Prostaglandins, endotoxins and uterine bacteriology in reproduction of the doe and cow. Thesis, Uppsala, 1984.

Granström E, Kindahl H: Radioimmunoassay of the major plasma metabolite of $\mathrm{PGF}_{2 \alpha}, 15$-keto-13, 14-dihydro PGF $_{2 \alpha}$. Methods Enzymol. 1982, 86, 320-339. 
Griel LC, Zarkower A, Eberhart RJ: Clinical and clinicopathological effects of Eschericia coli endotoxin in mature cattle. Can. J. comp. Med. 1975, $39,1-6$.

Hardee GE, Smith JA, Harris SJ: Pharmacokinetics of flunixin meglumine in the cow. Res. vet. Sci. 1985, 39, 110-112.

Luthman J, Jacobsson SO, Kindahl H: Influence of prostaglandins on calcium homeostasis in dairy cows. Zbl. Vet. Med. A, 1983, 30, 521-529.

Luthman J, Kindahl H, Jacobsson SO, Thunberg L: Local and general effects of Salmonella typhimurium endotoxin in calves. J. vet. med. A, 1988, 35, 586-595.

MacGregor RR: Granulocyte adherence changes induced by hemodialysis, endotoxin, epinephrine, and glucocorticoids. Ann. int. Med. 1977, 86, 3539.

Margolis JH, Bottoms GD, Fessler JH: The efficacy of dexamethasone and flunixin meglumine in treating endotoxin-induced changes in calves. Vet. Res. Comm. 1987, 11, 479-491.

Milton AS: Prostaglandins and fever. Trends in Pharmacol. Sci. 1982, 3, 490-492.

Mitchell RH, Kampschmidt RF: Leukocytic endogenous mediator in non-specific host defences. In: The Reticuloendothelial System. A Comprehensive treatise. Ed. Reichard SM, Filkins JP. Plenum Press, New York 1985.

Oppenheim JJ, Konvacs EJ, Matsushima K, Durim $S K$ : There is more than one interleukin - 1. Immunology Today. 1986, 7, 45-56.

Pekarek RS, Beisel WR: Characterization of the endogenous mediators of serum zinc and iron depression during infection and other stresses. Proc. Soc. exp. Biol. Med. 1971, 138, 728-732.

Sankari S, Pekkanen T: The effect of endotoxin on the liver lipid peroxide levels and on the liver and plasma zinc concentrations in rats. Acta vet. scand. 1982, 23, 24-29.

Schrauwen E, Vandeplasche G, Laekman $G$, Houvenaghel $A$ : Endotoxic shock in the piglet: Beneficial effects of prostaglandin synthesis inhibitors.
Prostaglandins Leukotrienes and Medicine 1984, 13, 271-278.

Van Miert ASJPAM, Van Duin CTM, Verheijden $J H M$, Schotman AJH: Endotoxin-induced fever and associated haematological and blood biochemical changes in the goat: The effect of repeated administration and the influence of flurbiprofen. Res. Vet. Sci. 1982, 33, 248-255.

Van Miert ASJPAM: Fever and associated clinical and blood biochemical changes in the goat and other animal species. Vet. Quart. 1985, 7, 200216.

Van Miert ASJPAM: Fever, anorexia and forestomach hypomotility in ruminants. Vet. Red. Comm. 1987, 11, 407-422.

\begin{abstract}
Sammenfattning
Inverkan av flunixin pả svaret pả Salmonella typhimurium endotoxin hos kalv.

Effekterna av intravenös injektion av endotoxin från Salmonella typhimurium i dosen $0.5 \mu \mathrm{g} / \mathrm{kg}$ kroppsvikt studerades hos kalv. Injektionen följdes av mycket tydliga kliniska symtom. Kalvarna visade tecken på reducerad förmagsmotorik och kraftigt stört allmäntillstånd. De kliniska symtomen försvann dock inom 24 timmar.

Plasmakoncentrationen av 15-ketodihydro-PGF $2 \alpha$ steg mycket påtagligt efter endotoxininjektionen. Vidare uppkom en mycket drastisk sänkning av antalet cirkulerande leukocyter och signifikanta sänkningar av serumkoncentrationerna av järn, zink och kalcium. För att studera vilken roll PG-frisättningen har för uppkomsten av de observerade blodkemiska förändringarna förbehandlades en grupp kalvar med flunixin, en potent PG synteshämmare. Flunixin blockerade frisättningen av PG fullständigt, men var helt utan effekt på övriga endotoxininducerade förändringar. Endotoxin gav ett mycket mảttligt pyrogensvar och det konkluderades att de känsligaste parametrarna for att studera endotoxineffekter hos kalv är antalet leukocyter och koncentrationerna av 15-ketodihydro-PGF $2 \alpha$, järn, zink och kalcium.
\end{abstract}

(Accepted September 16, 1988).

Reprints may be obtained from: Jan Luthman, Dept. of Cattle and Sheep Diseases, Faculty of Veterinary Medicine, Swedish University of Agricultural Sciences, S-750 07 Uppsala, Sweden. 